\title{
Serum Uric Acid and Homocysteine as Predictors of Pre-eclampsia
}

\author{
Sangeeta N ${ }^{1}$, Shaini $L^{1}$, Gomi Basar ${ }^{1 *}$, Soni Devi ${ }^{1}$, Vanlal Chhuangi ${ }^{1}$, Kanak Kanti Mandal ${ }^{1}$, Radhe Natung ${ }^{2}$, Ajit Kumar Y $^{3}$, Singh WG ${ }^{1}$ and \\ Amuba Singh $\mathbf{M}^{1}$
}

'Department of Biochemistry, RIMS, India

${ }^{2}$ Maulana Azad Medical College, New Delhi, India

${ }^{3}$ Department of Obstetrics and Gynaecology, RIMS, India

\begin{abstract}
Objective: To estimate the serum homocysteine and uric acid levels in normal and pre-eclamptic patients and to find out any correlation between these parameters and pre-eclampsia

Study design and setting: Cross-sectional study; Dept. of Biochemistry in collaboration with Department of Obstetrics and Gynaecology, Regional Institute of Medical Sciences (RIMS); Imphal (Manipur), India.

Methods: Data collected from 50 pre-eclamptic pregnant women and 25 normotensive pregnant women admitted in Antenatal ward, Department of Obstetrics and Gynaecology, RIMS Hospital. The blood samples were collected from these patients and analyzed for serum homocysteine and uric acid level.

Results: The serum homocysteine and uric acid levels were found to be significantly higher in preeclamptic cases than in normal controls. Mean \pm SD of uric acid and homocysteine levels were $8.82 \pm 1.68 \mathrm{mg} \%$ and $10.32 \pm$ $2.52 \mu \mathrm{mol} / / \mathrm{l}$ respectively in the cases compared to $4.06 \pm 0.96 \mathrm{mg} \%$ and $3.55 \pm 1.25 \mu \mathrm{mol} / \mathrm{l}$ in the controls. A positive correlation was found between the serum uric acid level, homocysteine and blood pressure. Thus the study showed a strong association between increased uric acid, blood pressure and homocysteine levels.
\end{abstract}

Keywords: Pre-eclampsia; Uric acid; Homocysteine

\section{Introduction}

Hypertension is one of the common complications during pregnancy and contributes significantly to maternal and perinatal morbidity and mortality. Pre-eclampsia is a type of hypertensive disorder complicating pregnancy. It is a multisystem disorder of unknown etiology characterized by development of hypertension to the extent of $140 / 90 \mathrm{mmHg}$ or more with proteinuria after the $20^{\text {th }}$ week in a previously normotensive and non-proteinuric patient. Its pathophysiology is poorly understood but currently endothelial dysfunction is most popularly hypothesized to be a central pathophysiological feature of preeclampsia leading to altered vascular reactivity,loss of vascular integrity and activation of the coagulation cascade [1].

Uric acid (UA) is the major end-product of purine metabolism. The cause of hyperuricemia in pre-eclampsia has been attributed to either a decreased excretion or to an increased production of uric acid. Decreased uric acid clearance, reflected by altered tubular function has been documented, while in 1990 Fay proposed an increased breakdown of purines in the placenta as a possible explanation for the overproduction of uric acid [2]. Hyperuricemia is one of the most consistent and earliest detectable changes in pre-eclampsia and has been cited as a better predictor of fetal risk than blood pressure $[3,4]$.

Homocysteine (Hcy), a thiol-containing amino acid, is the demethylated derivative of the essential amino acid methionine and thus an intermediate in the methionine cycle. Elevated homocysteine is a risk factor for endothelial dysfunction and vascular disease such as atherosclerosis and occlusive vascular disorders [5]. The mean homocysteine levels normally decrease with gestation either due to physiological response to the pregnancy, increase in estrogen, hemodilution from increased plasma volume or increased demand for methionine by both the mother and fetus [6]. The homocysteine-mediated vascular changes are similar to those associated with preeclampsia; therefore, it has been postulated that hyperhomocysteinemia may be associated with this condition [7].

The present study was conducted to estimate the serum homocysteine and uric acid levels in pre-eclamptic indigeneous Manipuri women and to find out any correlation between these parameters and the disease.

\section{Materials and Methods}

A case control study was conducted to evaluate the level of serum homocysteine in preeclamptic patients (cases) and normal pregnant women (controls) admitted in the antenatal ward in the Department of Obstetrics and Gynaecology. It was done in the Department of Biochemistry in collaboration with the Department of Obstetrics and Gynaecology, Regional Institute of Medical Sciences, Imphal. Patients who were diagnosed as preeclamptics were taken as the cases and normal pregnant women of comparable gestational age as the controls. Fifty pregnant women in the age group 18 to 45 years having blood pressure $\geq 140 / 90 \mathrm{mmHg}$ and proteinuria $\geq 300 \mathrm{mg}$ in a 24 hours urine collection after 20 weeks of gestation were recruited as preeclamptic cases. Another 25 normal pregnant women of similar age group and gestational age were also taken as controls. The study group and the control group were matched for age, weight and gestational age. All

*Corresponding author: Gomi Basar, PGT, Department of Biochemistry, Regional Institute of Medical Sciences, Imphal, Manipur, India -795004, Tel: +91 9436042415/+91 9774024415; Fax : 0385-2414625; E-mail drgomibasar@yahoo.co.in

Received March 27, 2013; Accepted April 23, 2013; Published April 28, 2013

Citation: Sangeeta N, Shaini L, Basar G, Soni Devi, Chhuangi V, et al. (2013) Serum Uric Acid and Homocysteine as Predictors of Pre-eclampsia. J Diabetes Metab 4: 259. doi:10.4172/2155-6156.1000259

Copyright: (c) 2013 Sangeeta N, et al. This is an open-access article distributed under the terms of the Creative Commons Attribution License, which permits unrestricted use, distribution, and reproduction in any medium, provided the original author and source are credited. 
Citation: Sangeeta N, Shaini L, Basar G, Soni Devi, Chhuangi V, et al. (2013) Serum Uric Acid and Homocysteine as Predictors of Pre-eclampsia. J Diabetes Metab 4: 259. doi:10.4172/2155-6156.1000259

Page 2 of 6

the cases and controls in the study were subjected to detailed history regarding age, parity, height and weight at the time of blood collection. Maternal education, religion, race, socioeconomic status, menstrual history, obstetric history was taken. General physical examinations and systemic examinations with special reference to oedema and blood pressure were carried out. And all the investigations were recorded in the proforma designed for the study. Those patients with preexisting hypertension, cardiovascular or renal diseases diabetes mellitus or chronic diseases and those patients on treatment with anti-folate drugs (antiepileptics, methotrexate) were excluded from the study. Ethical clearance was obtained from the Institutional Ethical Committee, Regional Institute of Medical Sciences, Imphal.

$5 \mathrm{ml}$ of venous blood was drawn from anterior cubital vein after an overnite fast. The sample was centrifuged for 10 minutes and analysed for total serum homocysteine and uric acid in the Department of Biochemistry, RIMS. Total serum homocysteine was carried out by Enzyme Linked Immunosorbant Assay (ELISA) method [8] using Axis-homocysteine Enzyme Immunoassay (EIA) kit from Ranbaxy Diagnostic Ltd. India. Serum uric acid was analyzed by Uricase method (enzymatic-colorimetric test) modified by Human Co., Germany $[9,10]$.

Statistical analysis was done using well known statistical formulae like $\chi^{2}$ - test, independent sample t-test; Pearson correlation coefficient "r" was used.

\section{Results}

Table 1 shows the distribution of preeclampsia women and normal pregnant women among the various religious groups. The majority of women in the case group are Hindus (70\%) whereas Muslims and Christian comprises of $20 \%$ and $10 \%$ respectively. In the control group Hindus comprises of $76 \%$ whereas Muslims and Christians comprises of $12 \%$ each. It is found that no significant difference $(\mathrm{p}=0.683)$ is observed between them.

Table 2 shows that majority of the women in the case group belong to the lowest socioeconomic group (60\%) followed by women belonging to medium (14\%) and high economic status $(12 \%)$ respectively. The pattern is found to exist in both the groups and no significant difference ( $\mathrm{p}=0.114)$ is observed.

Table 3 shows the distribution of controls and cases according to parity. It is seen that maximum number of cases $(50 \%)$ occur in primiparas $\left(\mathrm{P}_{0+0}\right), 20 \%$ belong to ${ }_{\mathrm{P}_{1+0}}, 20 \%$ belong to $\mathrm{P}_{2+0}$ and $10 \%$ belong to $\mathrm{P}_{3}$ and above. Insignificant value of $\chi^{2}=1.130 ; \mathrm{p}=0.769$ suggests that parity is matched between the groups.

It is evident from table 4 that maximum number of the cases occurs in the age group of 21-25 years. The women in control group have older age than that of the case group. However the difference is found to be insignificant at $5 \%$ probability level.

Table 5 shows that the mean age \pm standard deviation (SD) in years in the case and control group. The difference between the groups is not significant $(\mathrm{p}=0.380)$ indicating that both the groups are of comparable age.

Table 6 shows the distribution of cases and controls according to mean \pm SD of weight and haemoglobin. It is observed that mean weight of women in the case group $(52.46 \pm 5.09 \mathrm{Kg})$ is more compared to that of control group $(50.36 \pm 3.55 \mathrm{Kg})$ but the difference is not significant at $5 \%$ level of significance. The haemoglobin concentration is more in the controls $(11.20 \pm 1.27 \mathrm{gm} \%)$ compared to cases $(10.36 \pm 0.82$

\begin{tabular}{|c|c|c|c|}
\hline Religion & \multicolumn{2}{|c|}{ Group } & Total \\
\hline & Control group Number (\%) & Case group Number (\%) & \\
\hline Hindu & $19(76)$ & $35(70)$ & 54 \\
\hline Muslim & $3(12)$ & $10(20)$ & 13 \\
\hline Christian & $3(12)$ & $5(10)$ & 8 \\
\hline Total & $25(100)$ & $50(100)$ & 75 \\
\hline
\end{tabular}

$X^{2}=0.761 ; d f=2 ; p=0.683 \quad d f:$ Degree of Freedom

Table 1: Distribution of case and control group according to religion.

\begin{tabular}{|c|c|c|c|}
\hline \multicolumn{3}{|c|}{ Group } & Total \\
\hline * Socio-economic status & $\begin{array}{c}\text { Control group } \\
\text { Number (\%) }\end{array}$ & Case group Number (\%) & \\
\hline High & $7(28)$ & $6(12)$ & 13 \\
\hline Medium & $3(12)$ & $14(28)$ & 17 \\
\hline Low & $15(60)$ & $30(60)$ & 45 \\
\hline Total & $25(100)$ & $50(100)$ & 75 \\
\hline
\end{tabular}

$X^{2}=4.344 ; d f=2 ; p=0.114$

${ }^{*}$ Kuppuswamy socioeconomic status scale (1981)

Table 2: Distribution of case and control group according to socioeconomic status.

\begin{tabular}{|c|c|c|c|}
\hline \multicolumn{3}{|c|}{ Group } & \\
\hline * Parity & $\begin{array}{c}\text { Control group } \\
\text { Number (\%) }\end{array}$ & $\begin{array}{c}\text { Case group } \\
\text { Number (\%) }\end{array}$ & Total \\
\hline $\mathbf{P}_{0+0}$ & $15(60)$ & $25(50)$ & 40 \\
\hline $\mathbf{P}_{1+0}$ & $3(12)$ & $10(20)$ & 13 \\
\hline $\mathbf{P}_{2+0}$ & $4(16)$ & $10(20)$ & 14 \\
\hline $\mathbf{P}_{3}$ and above & $3(12)$ & $5(10)$ & 8 \\
\hline Total & $25(100)$ & $50(100)$ & 75 \\
\hline
\end{tabular}

$X^{2}=1.130 ; d f=3 ; p=0.769$

Table 3: Distribution of case and control group according to parity.

\begin{tabular}{|c|c|c|c|}
\hline Age (yr.) & Control group (\%) & Case group (\%) & Total \\
\hline Up to 20 & $1(4 \%)$ & $6(12 \%)$ & 7 \\
\hline $21-25$ & $8(32 \%)$ & $25(50 \%)$ & 33 \\
\hline $26-30$ & $10(40 \%)$ & $9(18 \%)$ & 19 \\
\hline $31-35$ & $4(16 \%)$ & $5(10 \%)$ & 9 \\
\hline 36 and above & $2(8 \%)$ & $5(10 \%)$ & 7 \\
\hline Total & 25 & 50 & 75 \\
\hline
\end{tabular}

$X^{2}=6.13 ; d f=4 ; p=0.189$

Table 4: Distribution of case and control group according to the age group

\begin{tabular}{|c|c|c|}
\hline Group & No. of patients & Mean \pm SD ( Years) \\
\hline Control group & 25 & $27.64 \pm 4.76$ \\
\hline Case group & 50 & $26.50 \pm 5.50$ \\
\hline
\end{tabular}

SD: Standard Deviation $\quad t=0.883 ; d f=73 ; p=0.380$

Table 5: Comparison of mean age \pm SD (years) of case and control groups.

\begin{tabular}{|l|l|l|l|l|l|l|l|}
\hline Parameter & Control group & \multicolumn{2}{l|}{ Case group } & t-value & df & p-value \\
\hline & No. cases & Mean \pm SD & No. cases & Mean \pm SD & & & \\
\hline Weight(kg) & 25 & $50.36 \pm 3.55$ & 50 & $52.46 \pm 5.09$ & 1.845 & 73 & 0.069 \\
\hline $\mathrm{Hb}(\mathrm{gm} \%)$ & 25 & $11.20 \pm 1.27$ & 50 & $10.36 \pm 0.82$ & 3.466 & 73 & 3.466 \\
\hline
\end{tabular}

SD: Standard Deviation; df: Degree of freedom

Table 6: Comparison of mean \pm SD of weight and haemoglobin between the case \& control group

$\mathrm{gm} \%)$. This difference is found to be statistically significant $(\mathrm{p}=0.001)$.

Table 7 shows that majority of the preeclamptic cases (70\%) shows the presence of both proteinuria and oedema.

It is evident from figure 1 that regarding the mode of deliveries, 


\begin{tabular}{|c|c|c|c|}
\hline Parameters & Present (\%) & Absent (\%) & Total \\
\hline Proteinuria & $30(60)$ & $20(40)$ & 50 \\
\hline Oedema & $30(60)$ & $20(40)$ & 50 \\
\hline Both & $35(70)$ & $15(30)$ & 50 \\
\hline
\end{tabular}

$X^{2}=1.44 ; \mathrm{df}=2 ; \mathrm{p}=0.487$

Table 7: Proteinuria and oedema in the case group.

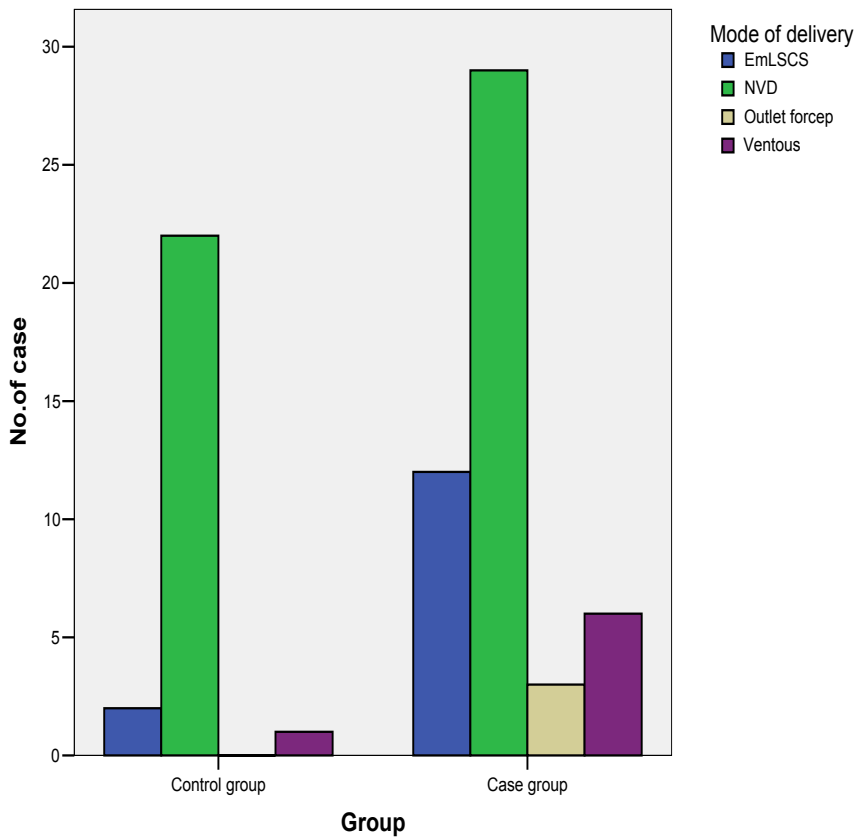

Figure 1: Comparison of mode of deliveries between the case and control group.

maximum number of cases (58\%) and controls (88\%) delivered by normal vaginal delivery (NVD) followed by caesarean section in $28 \%$ and $8 \%$ of the cases and controls respectively. Six percent of cases delivered by outlet forceps and the number of patients delivered by assisted ventouse are $12 \%$ and $4 \%$ in the cases and controls respectively. However insignificant test value $(\mathrm{p}=0.068)$ suggests that the mode of deliveries in both the groups are almost alike.

Figure 2 shows that the average gestational age at delivery for normal pregnant women $(39.00 \pm 1.19$ weeks $)$ is higher than of the cases ( $35.94 \pm 1.83$ weeks). The difference is very highly significant even at $0.1 \%$ probability level $(\mathrm{p}=0.000)$.

The weights of the babies born to normal pregnant controls are more than those born to the cases. Mean \pm SD $(\mathrm{Kg})$ in the control group is $3.11 \pm 0.36$ compared to $2.80 \pm 0.60$ in the case group as is evident from figure 3 . The difference is statistically significant at $5 \%$ probability level $(\mathrm{p}=0.023)$.

It is evident from table 8 that out of the 50 preeclamptic patients, $88 \%$ cases have no complications whilst $8 \%$ have intrauterine foetal dead (IUFD), $2 \%$ has abruptio placentae and $2 \%$ has congenital malformation. In the control group none has complications. The complications that occurred within the case group are found to be highly significant compared to normal pregnant controls $(\mathrm{p}<0.001)$.

Table 9 shows the comparison of mean \pm SD ( $\mathrm{mmHg}$ ) of blood pressure between the cases and controls. It is seen that the mean \pm $\mathrm{SD}$ of systolic as well as diastolic blood pressure level in preeclamptic women is much higher than that for normal pregnant women. This difference is found to be very highly significant $(\mathrm{p}=0.000)$.

The serum uric acid levels in the cases are higher than the controls (Figure 1). The mean $\pm \mathrm{SD}(\mathrm{mg} \%)$ for the cases is $8.82 \pm 1.68$ whereas in the control group it is $4.06 \pm 0.96$. This difference in the values is very highly significant $(\mathrm{p} \leq 0.001)$.

The level of serum homocysteine is higher in the case group compared to control group as evident in figure 2 . The mean \pm SD of homocysteine $(\mu \mathrm{mol} / \mathrm{l})$ in the case group is $10.32 \pm 2.52$ whereas the level in control is $3.55 \pm 1.25$. This variation is very highly significant as evident by very highly significant value of $\mathrm{t}=12.601$ and $\mathrm{p}=0.0001$.

Table 10 shows the level of homocysteine levels in preeclamptic (PET) cases according to blood pressure. It has been observed that out of 50 cases of preeclampsia, 30 preeclamptic patients have blood pressure between 140/90 $\mathrm{mm} \mathrm{Hg}$ and $160 / 110 \mathrm{mmHg}$ and 20

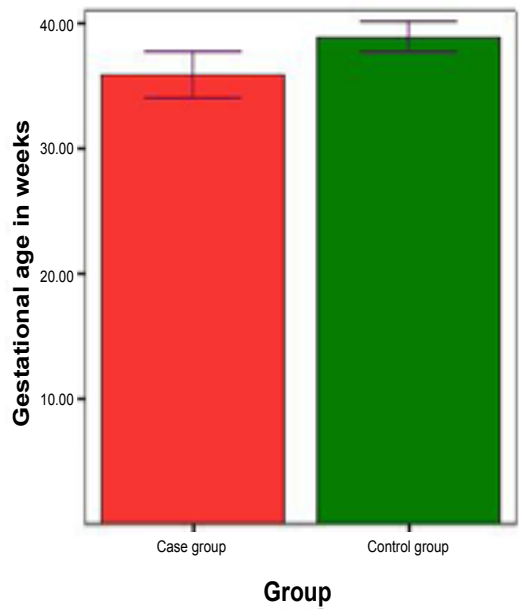

Error Bars show Mean $+/-1.0 \mathrm{SD}$ Bars show Means

SD: Standard Deviation

Figure 2: Comparison of Mean \pm SD of gestational age (weeks) at delivery between the case and control group.

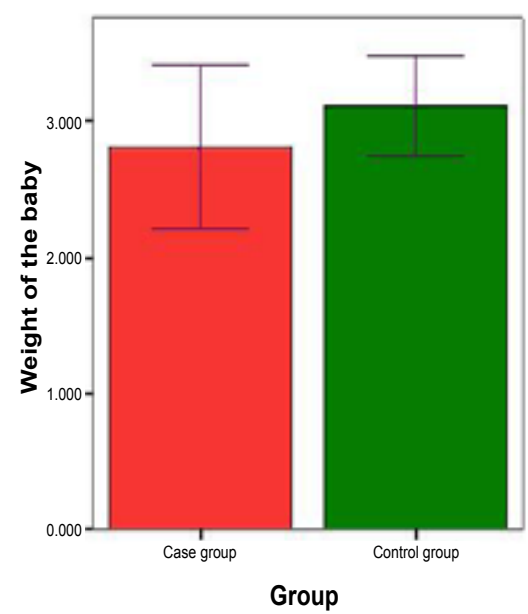

Error Bars show Mean + - $1.0 \mathrm{SD}$ Bars show Means

SD: Standard Deviation

Figure 3: Comparison of Mean $\pm \mathrm{SD}$ of weight of babies $(\mathrm{Kg})$ between the case and control group. 


\begin{tabular}{|c|c|c|c|}
\hline Complications & \multicolumn{2}{|c|}{ Group } & Total \\
\hline & Control group (\%) & Case group (\%) & \\
\hline Abruptio placentae & 0 & $1(2)$ & 1 \\
\hline Congenital malformation & 0 & $1(2)$ & 1 \\
\hline Intrauterine fetal death & 0 & $4(8)$ & 4 \\
\hline No complication & $25(100)$ & $44(88)$ & 69 \\
\hline Total & $25(100)$ & $50(88)$ & 75 \\
\hline
\end{tabular}

$X^{2}=106.320 ; d f=3 ; p=0.001$

Table 8: Distribution of case and control according to complications.

\begin{tabular}{|c|c|c|c|c|c|c|c|}
\hline $\begin{array}{c}\text { Parameter } \\
\text { value }\end{array}$ & \multicolumn{2}{|c|}{ Control group } & \multicolumn{2}{|c|}{ Case group } & t-value & df & p-value \\
\hline & No. cases & Mean \pm SD & $\begin{array}{c}\text { No. } \\
\text { cases }\end{array}$ & Mean \pm SD & & & \\
\hline Systolic 0.001 & 25 & $118.08 \pm 10.80$ & 50 & $155.80 \pm 10.65$ & 14.385 & 73 & $<$ \\
\hline $\begin{array}{c}\text { Diastolic } \\
0.0001\end{array}$ & 25 & $75.36 \pm 7.73$ & 50 & $103.16 \pm 15.37$ & -8.497 & 73 & $<$ \\
\hline
\end{tabular}

Table 9: Comparison of mean $\pm \mathrm{SD}$ of blood pressure $(\mathrm{mmHg})$ level between the case and control group.

\begin{tabular}{|c|c|c|c|}
\hline $\begin{array}{c}\text { Blood Pressure } \\
\text { Level(mmHg) }\end{array}$ & $\begin{array}{c}\text { Total No. of } \\
\text { Cases }\end{array}$ & \multicolumn{2}{|c|}{$\begin{array}{c}\text { No. of Cases (\%) according to } \\
\text { Homocysteine Level } \\
>10 \mu m o l / l\end{array}$} \\
\hline$>140 / 90<160 / 110$ & 30 & $18(60 \%)$ & $12(40 \%)$ \\
\hline$>160 / 110$ & 20 & $7(25 \%)$ & $13(65 \%)$ \\
\hline Total & 50 & 25 & 25 \\
\hline
\end{tabular}

$X^{2}=2.080 ; d f=1 ; p=0.148$

Table 10: Homocysteine levels in preeclamptic (PET) cases according to blood pressure.

preeclamptic patients have blood pressure above 160/110 mmHg. In the mild preeclamptic cases majority has homocysteine level below 10 $\mu \mathrm{mol} / \mathrm{l}$ whereas in the severe preeclamptic cases majority of them has level above $10 \mu \mathrm{mol} / \mathrm{l}$. But the difference is not significant $(\mathrm{p}=0.148)$.

In order to study the correlation among the parameters; serum homocysteine, blood pressure, and serum uric acid - Pearson correlation coefficient " $\mathrm{r}$ " is advocated and findings are shown in table 11. The analysis is based on the case group only. Table 11 highlights that there is a strong positive correlation between serum homocysteine with blood pressure (systolic and diastolic) which is highly significant. A positive correlation is also observed between serum serum uric acid and homocysteine.

\section{Discussion}

The study shows that majority of the patients are Hindus (70\%) followed by Muslims (20\%) and Christians (10\%) as shown in table 1. This pattern is observed in both the cases and controls and no significant difference $(p=0.683)$ is found between them. The reason may be due the fact that the study is being conducted in the Hindu dominated area.

In the case of socioeconomic status, women in the lowest status (60\%) have the highest frequency followed by medium class $(28 \%)$ and least number of cases belongs to high socioeconomic class (12\%) as shown in table 2. The pattern is found to exist in both groups and no significant difference $(\mathrm{p}=0.114)$ is observed between the groups.

Maximum number of cases is observed in the primigravida (50\%) and only $10 \%$ of the cases are seen above third gravida (Table 3 ). Ingec have also reported that preeclampsia occurs more commonly in primiparas compared to normal controls.

In the present study maximum numbers of preeclamptic cases occur in the age group of $21-25$ years (59\%) and only $10 \%$ occurs at 36 years and above (Table 4).The women in the control group are older than women in the case group. However, the difference is found to be insignificant at $5 \%$ probability level. Table 5 shows that the mean age $\pm \mathrm{SD}$ of the cases is $26.50 \pm 5.50$ years. This finding is similar to the finding of Powers who found the mean age \pm SD to be $26.2 \pm 5.8$ years.

On comparison of weight and haemoglobin between the cases and controls (Table 6), it has been observed that the weights of women belonging to the case group are heavier than the controls. Mean weight $\pm \mathrm{SD}$ of the cases is $52.46 \pm 5.50 \mathrm{~kg}$ compared to $50.36 \pm 3.55 \mathrm{~kg}$ in control but the difference is not statistically significant $(\mathrm{p}=0.069)$. This finding is in agreement with that of Rajkovic et al. [11] who found in their study that the weights of the preeclamptic women were more than that of the normal pregnant controls.

It is evident from table 7 that maximum cases (70\%) show the presence of both proteinuria and oedema whilst proteinuria and oedema alone are seen in $60 \%$ each.

The study shows that out of the 50 preeclamptic cases, $44(88 \%)$ cases have no complications, one case (2\%) delivered a baby with congenital malformation, one case $(2 \%)$ has abruptio placenta and another $8 \%$ have intrauterine foetal death (Table 8 ). No complication is seen in the control group. The difference in complication between the cases and controls is highly significant $(\mathrm{p}=0.001)$.

Our study shows blood pressure is higher in the cases compared to controls and the difference is highly significant as shown in table 9. The serum uric acid level is higher in the cases than the controls (Figure 4) and the difference is highly significant. During pregnancy maternal serum uric acid levels initially falls, with a subsequent rise to prepregnancy levels near term [12]. The third -trimester rise in uric acid may be related to an increase in foetal uric acid production or a decrease in uric acid clearance [13]. Elevated serum uric acid levels due to decreased renal urate excretion are frequently found in women with preeclampsia [14]. Soluble uric acid impairs nitric oxide generation in endothelial cells inducing endothelial dysfunction [15]. Besides the reduced clearance hyperuricemia in pre-eclampsia may be due to increased uric acid production caused by trophoblast breakdown, cytokine release and ischemia. Uric acid can promote endothelial dysfunction, damage and inflammation, which leads to oxidation. So, pre-eclampsia, which is characterized by widespread endothelial dysfunction and inflammation, might be propagated by uric acid [16] It has also been reported that rise in uric acid level in preeclampsia is secondary to placental damage leading to purine catabolism and production of uric acid. Besides the increased uric acid level in our cases a positive correlation is observed between serum uric acid and homocysteine (Table 11). This supports the finding of Ingec et al. [17].

The serum homocysteine level in the case group is found to be highly significant compared to the control group (Figure 5). The findings are comparable to that reported by Rajkovic et al. [11], Sanchez et al. [18], Harma et al. [19] and Maruotti et al. [20]. A positive correlation is

\begin{tabular}{|c|c|c|c|c|}
\hline & $\begin{array}{c}\text { Serum } \\
\text { Homocysteine }\end{array}$ & SBP & DBP & $\begin{array}{c}\text { Serum uric } \\
\text { acid } \mathbf{~ m g} \%\end{array}$ \\
\hline Serum Homocysteine & 1 & $0.636\left(^{*}\right)$ & $0.610\left(^{*}\right)$ & 0.029 \\
\hline SBP & $0.636\left(^{*}\right)$ & 1 & $0.686\left(^{*}\right)$ & 0.032 \\
\hline DBP & $0.610\left(^{*}\right)$ & $0.686\left(^{*}\right)$ & 1 & 0.007 \\
\hline Serum uric acid mg\% & 0.029 & 0.032 & 0.007 & 1 \\
\hline
\end{tabular}

* Correlation is significant at the 0.01 level

Table 11: Correlation matrix of serum homocysteine, blood pressure \& serum uric acid. 


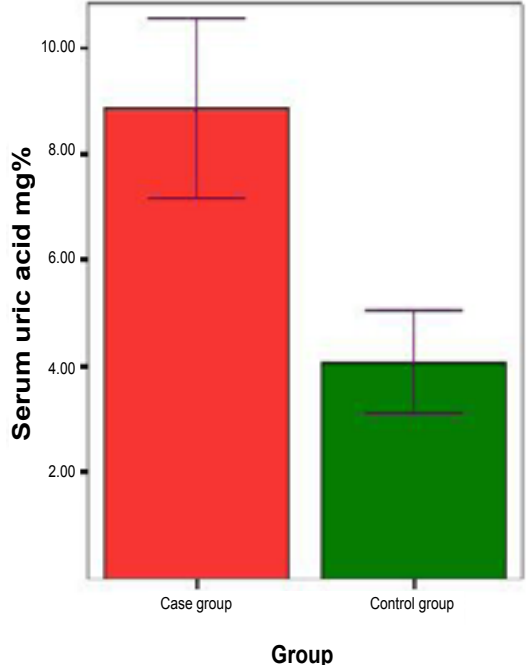

Error Bars show Mean + - 1.0 SD Bars show Means

Figure 4: Comparison of mean $\pm \mathrm{SD}$ of serum uric acid $(\mathrm{mg} \%)$ between the case and control group.

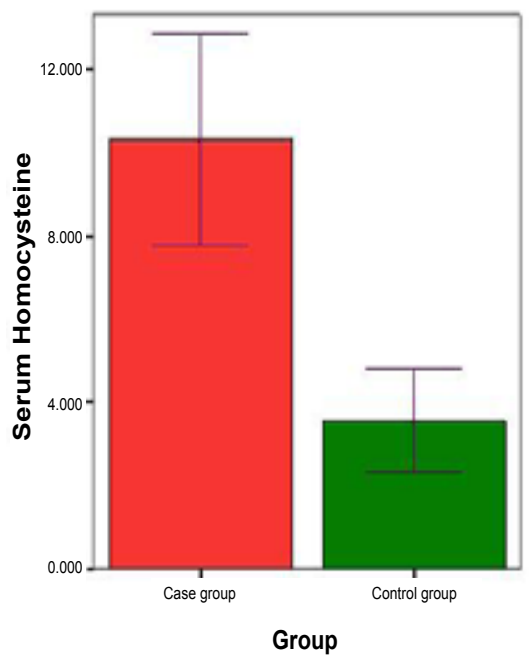

Error Bars show Mean + - $1.0 \mathrm{SD}$ Bars show Means

Figure 5: Comparison of mean $\pm \mathrm{SD}$ of serum homocysteine $(\mu \mathrm{mol} / \mathrm{l})$ between the case and control group.

seen between serum homocysteine and blood pressure (Table 11). This finding is in agreement with the finding of Ingec et al. [16]. Usually the homocysteine level decreased during pregnancy due to various factors. In the second and third trimesters total plasma homocysteine concentrations in maternal plasma reach only $\sim 50 \%$ of those non pregnant women. The decreased level with gestation may be either due to physiological response to the pregnancy, increase in estrogen, hemodilution from increased plasma volume or increased demand for methionine by both the mother and fetus. Studies involving patients with renal disease show an inverse correlation between homocysteine and glomerular filtration rate (GFR) [21]. The GFR increases on an average by $50 \%-70 \%$ above prepregnant levels as early as 5 weeks of gestation and remains elevated throughout pregnancy. However increase in renal function is compromised during preeclampsia [22]. Elevated circulating homocysteine is a risk factor for endothelial dysfunction and vascular disease such as atherosclerosis and occlusive vascular disorders [23]. It has been suggested that the adverse vascular effects of high homocysteine are mediated by oxidative inactivation of nitric oxide, a powerful endogenous vasodilator released from endothelium [24].

The increased uric acid and homocysteine levels in our cases may be due to derangement in the metabolism that usually decreases their levels during pregnancy. Their increased levels might have led to endothelial dysfunction which eventually results in preeclampsia. The study also shows a strong association between hyperuricemia, hyperhomocysteinemia and preeclampsia.

\section{Conclusion}

The results of this study confirm the hypothesis that hyperuricemia and hyperhomocysteinemia are indirect risk factors for preeclampsia. Thus it can be concluded that hyperuricemia and hyperhomocysteinemia can be used as biomarkers for identifying women at risk of complications and adverse pregnancy outcomes.

Several potential limitations of our study are worth mentioning. All the cases were preeclamptic before the measurement of serum uric acid and homocysteine levels and, so it cannot be determined whether the observed elevation in homocysteine and uric acid preceded the development of preeclampsia. Hyperhomocysteinemia and hyperuricemia in preeclampsia patients need to be confirmed in a design in which uric acid and homocysteine are measured before the development of preeclampsia or early in pregnancy in order to identify and monitor the patients at risk and thus provide the best prenatal care for these women and their babies.

\section{References}

1. Adegoke OA, Iyare EE, Gbenebitse SO (2003) Fasting plasma glucose and cholesterol levels in pregnant Nigerian women. Niger Postgrad Med J 10: 32 36 .

2. Jeyabalan A, Conrad KP (2007) Renal function during normal pregnancy and preeclampsia. Front Biosci 12: 2425-2437.

3. Redman CW, Beilin LJ, Bonnar J, Wilkinson RH (1976) Plasma-urate measurements in predicting fetal death in hypertensive pregnancy. Lancet 1 : 1370-1373.

4. Chesley LC (1985) Diagnosis of preeclampsia. Obstet Gynecol 65: 423-425

5. Allain CC, Poon LS, Chan CS, Richmond W, Fu PC (1974) Enzymatic determination of total serum cholesterol. Clin Chem 20: 470-475.

6. Also-Rallo E, Lopez-Quesada E, Urreizti R, Vilaseca MA, Lailla JM, et al. (2005) Polymorphisms of genes involved in homocysteine metabolism in preeclampsia and in uncomplicated pregnancies. Eur J Obstet Gynecol Reprod Biol 120: 45-52.

7. Andersson A, Brattström L, Israelsson B, Isaksson A, Hamfelt A et al. (1992) Plasma homocysteine before and after methionine loading with regard to age, gender, and menopausal status. Eur J Clin Invest 22: 79-87.

8. Frantzen F, Faaren AL, Alfheim I, Nordhei AK (1998) Enzyme conversion immunoassay for determining total homocysteine in plasma or serum. Clin Chem 44: 311-316.

9. Fossati P, Prencipe L, Berti G (1980) Use of 3,5-dichloro-2 hydroxybenzenesulfonic acid/4-aminophenazone chromogenic system in direct enzymic assay of uric acid in serum and urine. Clin Chem 26: 227-231.

10. Valero De Bernabé J, Soriano $T$, Albaladejo $R$, Juarranz $M$, Calle ME, et al. (2004) Risk factors for low birth weight: a review. Eur J Obstet Gynecol Reprod Biol 116: 3-15.

11. Rajkovic A, Catalano PM, Malinow MR (1997) Elevated homocyst(e)ine levels with preeclampsia. Obstet Gynecol 90: 168-171.

12. Lind T, Godfrey KA, Otun H, Philips PR (1984) Changes in serum uric acid concentrations during normal pregnancy. Br J Obstet Gynaecol 91: 128-132. 
Citation: Sangeeta N, Shaini L, Basar G, Soni Devi, Chhuangi V, et al. (2013) Serum Uric Acid and Homocysteine as Predictors of Pre-eclampsia. J Diabetes Metab 4: 259. doi:10.4172/2155-6156.1000259

13. Dunlop W, Davison JM (1977) The effect of normal pregnancy upon the renal handling of uric acid. Br J Obstet Gynaecol 84: 13-21.

14. Kang DH, Finch J, Nakagawa T, Karumanchi SA, Kanellis J, et al. (2004) Uric acid, endothelial dysfunction and pre-eclampsia: searching for a pathogenetic link. J Hypertens 22: 229-235.

15. Khosla UM, Zharikov S, Finch JL, Nakagawa T, Roncal C, et al. (2005) Hyperuricemia induces endothelial dysfunction. Kidney Int 67: 1739-1742.

16. Martin AC, Brown MA (2010) Could uric acid have a pathogenic role in preeclampsia? Nat Rev Nephrol 6: 744-748.

17. Ingec M, Borekci B, Kadanali S (2005) Elevated plasma homocysteine concentrations in severe preeclampsia and eclampsia. Tohoku J Exp Med 206: 225-231.

18. Sanchez SE, Zhang C, Rene Malinow M, Ware-Jauregui S, Larrabure G, et al. (2001) Plasma folate, vitamin B(12), and homocyst(e)ine concentrations in preeclamptic and normotensive Peruvian women. Am J Epidemiol 153: 474480
19. Harma M, Harma M, Kocyigit A (2005) Correlation between maternal plasma homocysteine and zinc levels in preeclamptic women. Biol Trace Elem Res 104: 97-105.

20. Maruotti G, Del Bianco A, Amato AN, Lombardi L, Fulgeri AM, et al. (2005) [Preeclampsia and high serum levels of homocysteine]. Minerva Ginecol 57 165-170.

21. Arnadottir M, Hultberg B, Nilsson-Ehle P, Thysell H (1996) The effect of reduced glomerular filtration rate on plasma total homocysteine concentration. Scand J Clin Lab Invest 56: 41-46.

22. Conrad KP, Lindheimer MD (1999) Renal and cardiovascular alterations in Chesley's Hypertensive Disorders in Pregnancy. P263-326.

23. Refsum H, Ueland PM, Nygård O, Vollset SE (1998) Homocysteine and cardiovascular disease. Annu Rev Med 49: 31-62.

24. Weiss N, Zhang YY, Heydrick S, Bierl C, Loscalzo J (2001) Overexpression of cellular glutathione peroxidase rescues homocyst(e)ine-induced endothelial dysfunction. Proc Natl Acad Sci U S A 98: 12503-12508. 